\title{
Plasma Glial Fibrillary Acidic Protein Levels in a Child with Sickle Cell Disease and Stroke
}

\author{
William J. Savage ${ }^{a, b} \quad$ Allen D. Everett ${ }^{c} \quad$ James F. Casella ${ }^{b}$ \\ a Division of Transfusion Medicine, Department of Pathology, and Divisions of bediatric Hematology and \\ cPediatric Cardiology, Department of Pediatrics, Johns Hopkins University, Baltimore, Md., USA
}

\section{Key Words}

Chronic transfusion - Glial fibrillary acidic protein •

Sickle cell $\cdot$ Stroke

\begin{abstract}
A 12-year-old boy with HbSS sickle cell disease (SCD) was admitted with an acute febrile illness and developed overt stroke 3 days later. Plasma glial fibrillary acidic protein levels were elevated, as compared to pediatric controls, $32 \mathrm{~h}$ prior to the clinical diagnosis of stroke, peaked immediately prior to the exchange transfusion, and remained elevated 1 year later despite chronic transfusion therapy. Stroke in SCD can occur in the setting of acute illness, and a biomarker that could predict the onset and triage ill children to therapeutic intervention more quickly would be useful.
\end{abstract}

Copyright $\odot 2010$ S. Karger AG, Basel

\section{Introduction}

Overt stroke occurs in approximately $10 \%$ of children with sickle cell disease (SCD) [1]. The cause of stroke in SCD is multifactorial and involves hemolysis, endothelial dysfunction, chronic inflammation, hypercoagulability, and altered adherent properties of sickled red blood cells
[2]. Management of acute stroke includes emergent red cell exchange followed by chronic red cell transfusion indefinitely $[3,4]$. Glial fibrillary acidic protein (GFAP) is a brain-specific cytoskeletal protein that is a well-studied biomarker of brain injury in animal models and clinical settings of brain injury, including acute stroke in adults [5-8]. To our knowledge, using a blood biomarker to predict, diagnose, or track stroke outcomes in SCD has not been reported. In an ongoing proteomic study, we observed that GFAP was detectable in cross sectional plasma samples from clinically well children with SCD. We hypothesized that longitudinal plasma levels of GFAP in a child with SCD and acute stroke would detect ongoing brain injury.

\section{Methods}

GFAP was measured using an electrochemiluminescent immunoassay (MesoScale Discovery) that is based on the assay of Petzold et al. [9]. Briefly, GFAP was measured in undiluted duplicate plasma samples using the monoclonal anti-GFAP blend SMI26 (Covance, Princeton, N.J., USA). GFAP at $100 \mathrm{ng}$ in $30 \mu \mathrm{lBS}$ per well was incubated overnight in standard-bind MSD plates for capture. Polyclonal anti-GFAP (Dako, Carpinteria, Calif., USA) directly conjugated with Sulfo-Tag (MesoScale Discovery) was used for detection at $1 \mu \mathrm{g} / \mathrm{ml}$ in PBS. Standard curves were made with 4-fold dilutions of purified GFAP (Calbiochem, La Jolla,

\section{KARGER}

Fax +41613061234 E-Mail karger@karger.ch www.karger.com
(C) 2010 S. Karger AG, Basel

0001-5792/11/1253-0103\$38.00/0

Accessible online at:

www.karger.com/aha
William J. Savage, MD

Carnegie 667

600 N. Wolfe St.

Baltimore MD 21287 (USA)

Tel. +1 443691 6014, Fax +1 410955 0618, E-Mail wsavage1@ jhmi.edu 

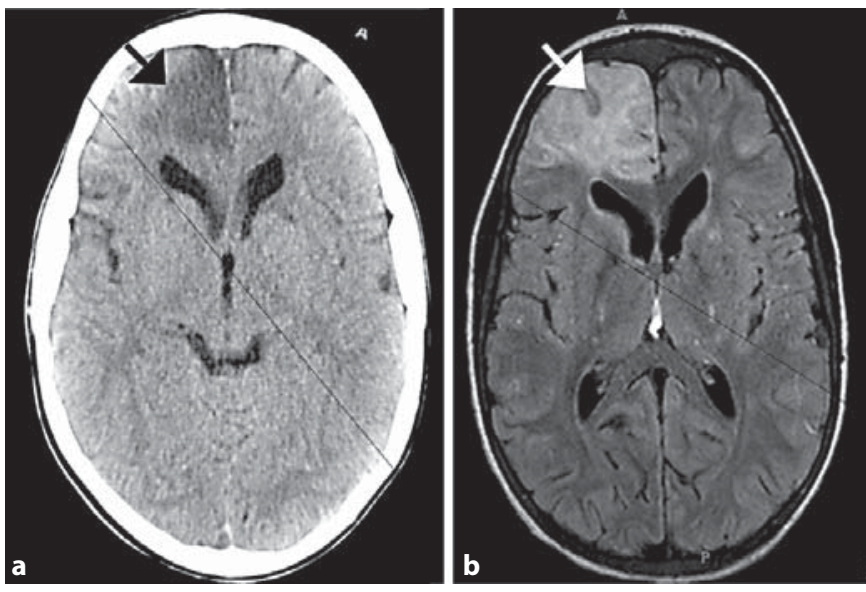

Fig. 1. Neuroimaging of acute stroke in a 12-year-old HbSS patient who had plasma GFAP followed serially. a Noncontrast head CT immediately after clinical diagnosis of stroke showing a wedge of hypoattenuation in the right frontal lobe (arrow). b FLAIR MRI image $29 \mathrm{~h}$ after clinical diagnosis of stroke showing an evolving right anterior cerebral artery infarct (arrow).

Calif., USA) in 1\% bovine serum albumin (SeraCare Life Sciences, Milford, Mass., USA). Plasma samples were obtained from discard blood procured as part of an IRB-approved research study with an informed consent exemption. Samples were frozen at $-80^{\circ} \mathrm{C}$ until assayed. Sixty children, aged 5-16 years, were selected as pediatric controls. Healthy controls were free of acute illness and any chronic illness other than obesity, asthma, and behavior disorders. Stability of GFAP at room temperature was demonstrated for $48 \mathrm{~h}$ with a $\mathrm{CV}$ of $2.5 \%$ at $2 \mathrm{ng} / \mathrm{ml}$ and $12.1 \%$ at $0.2 \mathrm{ng} / \mathrm{ml}$.

\section{Case Report}

A 12-year-old, right-handed boy with HbSS SCD was admitted for vomiting, diarrhea, chest pain, fever to $39^{\circ} \mathrm{C}$, and hypoxemia. He was initially managed with oxygen and intravenous fluids, morphine, ketorolac, and ceftriaxone. Serial chest X-rays showed no pulmonary infiltrate, and blood, stool, and urine cultures were negative. Oral oxycodone was substituted for IV morphine, and he was weaned off oxygen. The patient improved clinically and was preparing on hospital day 3 for discharge the following day, but in the night of hospital day 3 he became confused, and on hospital day 4 the patient was noted to have a fever to $40^{\circ} \mathrm{C}$, be uncommunicative with his parents, and have mild left arm and leg weakness. A CT of the head was performed which showed a large wedge-shaped right frontal infarct with a mild mass effect. Manual red blood cell exchange was performed emergently, with a reduction in $\mathrm{HbS}$ from 80.3 to $29.8 \%$. Ceftriaxone was increased to doses appropriate for meningitis, and vancomycin was started. He was subsequently noted to be minimally verbal, incontinent of urine and stool, and hemiplegic on the left side. MRI images $29 \mathrm{~h}$ after the diagnosis of stroke confirmed a right frontal lobe infarct in the ACA distribution (fig. 1). Multiple T2 and FLAIR hyperin- tense lesions that did not show restricted diffusion were present in the left centrum semiovale and frontal white matter, indicating prior cerebral infarcts that were not previously apparent clinically. CSF examination showed $6 \mathrm{WBC} / \mu \mathrm{l}$ and $2 \mathrm{RBC} / \mu \mathrm{l}$, and CSF cultures were negative. Neurologic improvement was noted after the first red cell exchange, but the patient became aphasic $48 \mathrm{~h}$ after his initial stroke, and CT and subsequently MRI confirmed a new left operculum infarct (not shown). A second manual red cell exchange was performed with a final $\mathrm{HbS}$ of $13.9 \%$. The patient was discharged to an inpatient rehabilitation hospital 8 days after the initial stroke and received monthly red blood cell transfusions to maintain an $\mathrm{HbS}<30 \%$. Sixteen weeks after the initial stroke, the patient underwent a pial synangiosis procedure for severe moyamoya disease combined with the history of stroke. In 1 year of follow-up from the initial stroke, there have been no additional neurologic events. Brain MRI performed at 4, 6, and 12 months after the stroke showed no new ischemic changes. A transcranial Doppler ultrasound had been performed at 8 years of age that demonstrated normal timed average mean velocities in the middle cerebral arteries $(159 \mathrm{~cm} / \mathrm{s}$ left and $153 \mathrm{~cm} / \mathrm{s} \mathrm{right)}$ indicating no increased risk of stroke at that time.

GFAP Levels in Controls and in a Patient with Overt Stroke

The 95th percentile cutoff of GFAP among pediatric controls was $0.227 \mathrm{ng} / \mathrm{ml}$. The patient's sibling, who is matched for disease but not neurologic injury, also served as a control. One week after the stroke in the propositus, the patient's sister, an 8 year old also with homozygous SCD, developed a febrile illness without neurologic sequelae, and her plasma GFAP concentration during the illness was $0.088 \mathrm{ng} / \mathrm{ml}$.

The first plasma sample available for the analysis was collected $32 \mathrm{~h}$ prior to the clinical diagnosis of stroke (fig. 2). This initial GFAP concentration of $1.5 \mathrm{ng} / \mathrm{ml}$ was 6.6 -fold higher than the normal 95 th percentile of pediatric controls $(0.227 \mathrm{ng} / \mathrm{ml})$ and $17-$ fold higher than the sibling control.

Plasma GFAP peaked at $2.83 \mathrm{ng} / \mathrm{ml}$ at the time of CT imaging and immediately prior to the first red cell exchange. Blood samples were obtained within $1 \mathrm{~h}$ of commencing red cell exchange and within $1 \mathrm{~h}$ after the completion of the exchange. Plasma GFAP decreased $42 \%$ after the first red cell exchange but decreased by only $13 \%$ after the second red cell exchange (fig. 2). The GFAP level in the CSF 1 day after the diagnosis of stroke was $44.6 \mathrm{ng} / \mathrm{ml}$. The most applicable reference value for GFAP in CSF is derived from pediatric acute lymphoblastic leukemia patients $<17$ years of age in whom CSF GFAP concentrations range from 0.1 to 0.5 $\mathrm{ng} / \mathrm{ml}[10]$.

Four weeks after the initial stroke and immediately prior to his first scheduled red cell transfusion, plasma GFAP was in the normal range. Subsequently, GFAP levels remained markedly elevated for up to 54 weeks.

\section{Discussion}

This patient, with symptoms of gastroenteritis, SCDrelated pain, and no clinical evidence of neurologic injury, had a markedly elevated GFAP prior to developing clinical evidence of stroke. This initial elevation was fol- 
lowed by a peak GFAP at the time of clinical stroke diagnosis and a decline to normal levels 4 weeks later after 2 red cell exchanges. Elevated GFAP prior to the onset of overt stroke may arise from several causes. There was evidence of prior silent cerebral infarcts on the initial MRI, and elevated GFAP prior to overt stroke may represent elevation from a prior ischemic event. Another possibility is that in the evolution of stroke in SCD, GFAP is an early indicator of brain injury.

The pattern of GFAP levels peaking at the time of stroke and decreasing exponentially immediately after suggests that GFAP tracked the evolution and resolution of stroke. The acute decline in GFAP after red cell exchange may be attributed to treatment efficacy, plasma dilution, a decreased release of GFAP into circulation, or enhanced clearance via renal or proteolytic pathways. Certainly, red cell exchange must dilute plasma GFAP concentrations to some degree because manual red cell exchanges remove whole blood; however, the red cell exchanges reduced GFAP by a disproportionately low amount. The first red cell exchange reduced $\mathrm{HbS}$ by $63 \%$ and GFAP by $42 \%$, and the second exchange reduced $\mathrm{HbS}$ by $46 \%$ and GFAP by $13 \%$. Thus, the change in GFAP cannot be entirely explained by plasma dilution. It is likely that an ongoing release of GFAP into the circulation mitigates the dilutive effect of red cell exchange. The elevation of plasma GFAP after effective transfusion and before surgery is more difficult to interpret but is highly suggestive of continuing or recurrent subclinical brain injury.

Despite the reduction in GFAP after the stroke in this child, GFAP became elevated again and remained elevated for a year after his stroke. Chronic elevation of a brainspecific protein may reflect chronic ischemic injury, even though this child had stable disease on serial brain MRIs. Indeed, the presence of moyamoya implies chronic ischemia, even if the regions of infarct on MRI are stable. Thus, elevated GFAP may be a more sensitive marker of subtle brain injury than MRI alone under select circumstances.

GFAP expression is highly restricted to the brain [11], and several studies have taken advantage of this fact to use GFAP as a biomarker of brain injury in other high risk settings, including traumatic brain injury [12], hypoxic ischemic encephalopathy [13], sepsis [14], and brain tumor diagnosis [15]. What is clear from these studies is that GFAP is highly specific for diagnosing brain injury and, therefore, a good measure for ruling in brain injury. Thus, the observation of elevated levels of GFAP that correlate with clinical findings of overt stroke and brain im-

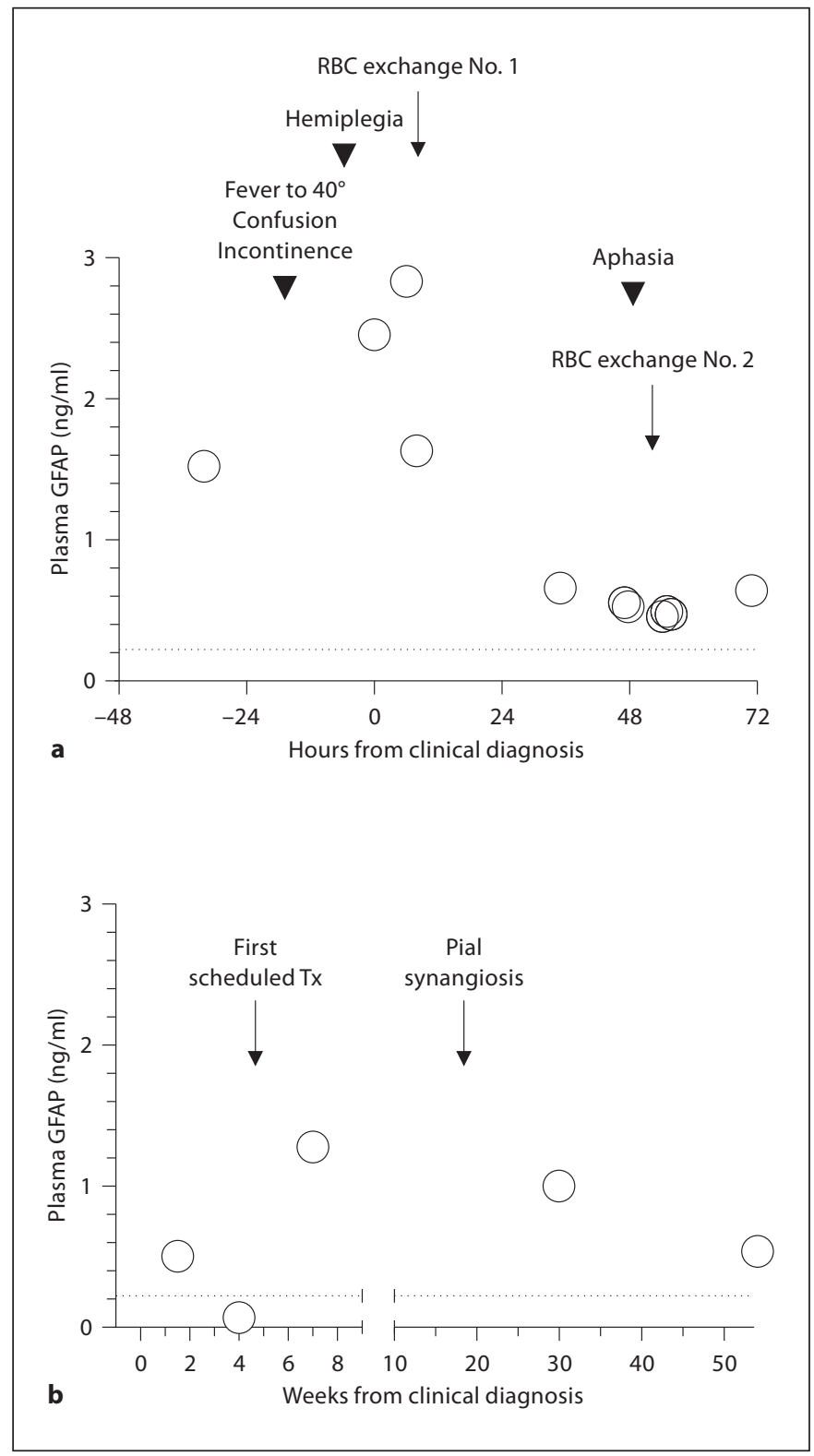

Fig. 2. a Serial plasma GFAP levels in a 12-year-old patient with $\mathrm{HbSS}$ and acute stroke. A red cell exchange transfusion was performed $5 \mathrm{~h}$ after clinical diagnosis and again $47 \mathrm{~h}$ later for new neurologic deficits. The dotted line marks the 95th percentile value among 60 healthy pediatric controls. Arrowheads mark the presentation of relevant signs and symptoms. b Fifty-four weeks of follow-up GFAP measurements.

aging in this patient make it likely that the GFAP levels reflect brain injury.

The elevation of plasma GFAP in this HbSS patient before the diagnosis of overt stroke raises the possibility that GFAP can detect subclinical brain injury and could 
be used as a screening test in ill patients with SCD as approximately $19 \%$ of strokes in pediatric SCD patients are associated with antecedent conditions [16]. Transcranial Doppler has been an effective tool for identifying children at risk of stroke, and initiating transfusion therapy in these children leads to a profound reduction in stroke risk [17]. Studies to test whether a blood biomarker can predict stroke risk would be a useful adjunct to current screening because blood is easy to obtain frequently, especially during times of increased risk for stroke. Patients identified at a higher risk could be triaged to brain MRI evaluation or close clinical follow-up.

Brain injury biomarkers could also be used potentially to track treatment efficacy. There is evidence in this report that exchange transfusion is associated with a de- crease in GFAP. There are too few GFAP measurements after pial synangiosis to make reasonable conclusions about how well GFAP may track the benefits of this procedure, although the GFAP decreased after the surgery. Future studies to correlate posttreatment GFAP levels with neurologic and neurovascular outcomes could yield important prognostic information. Evaluation of GFAP and other potential biomarkers of brain injury in SCD are worthy of further study.

\section{Acknowledgments}

This work was supported by the Clinical Hematology Scholars Program (K12 HL087169), the Sickle Cell Basic and Translational Research Program (U54 HL090515), and R01HL091759.

\section{References}

1 Ohene-Frempong K, Weiner SJ, Sleeper LA, Miller ST, Embury S, Moohr JW, Wethers DL, Pegelow CH, Gill FM: Cerebrovascular accidents in sickle cell disease: rates and risk factors. Blood 1998;91:288-294.

\2 Kato GJ, Hebbel RP, Steinberg MH, Gladwin MT: Vasculopathy in sickle cell disease: biology, pathophysiology, genetics, translational medicine, and new research directions. Am J Hematol 2009;84:618-625.

3 Verduzco LA, Nathan DG: Sickle cell disease and stroke. Blood 2009;114:5117-5125.

4 Adams RJ, Brambilla D: Discontinuing prophylactic transfusions used to prevent stroke in sickle cell disease. N Engl J Med 2005;353: 2769-2778.

5 Woertgen C, Rothoerl RD, Wiesmann M Missler U, Brawanski A: Glial and neuronal serum markers after controlled cortical impact injury in the rat. Acta Neurochir Suppl 2002;81:205-207.

-6 Herrmann M, Vos P, Wunderlich MT, de Bruijn CH, Lamers KJ: Release of glial tissuespecific proteins after acute stroke: a comparative analysis of serum concentrations of protein S-100B and glial fibrillary acidic protein. Stroke 2000;31:2670-2677.

7 Wunderlich MT, Wallesch CW, Goertler M: Release of glial fibrillary acidic protein is related to the neurovascular status in acute ischemic stroke. Eur J Neurol 2006;13:11181123.
-8 Vos PE, Lamers KJ, Hendriks JC, van Haaren M, Beems T, Zimmerman C, van Geel W, de Reus H, Biert J, Verbeek MM: Glial and neuronal proteins in serum predict outcome after severe traumatic brain injury. Neurology 2004;62:1303-1310.

9 Petzold A, Keir G, Green AJ, Giovannoni G, Thompson EJ: An ELISA for glial fibrillary acidic protein. J Immunol Methods 2004; 287:169-177.

10 Osterlundh G, Kjellmer I, Lannering B, Rosengren L, Nilsson UA, Marky I: Neurochemical markers of brain damage in cerebrospinal fluid during induction treatment of acute lymphoblastic leukemia in children. Pediatr Blood Cancer 2008;50:793-798.

11 Eng LF, Ghirnikar RS, Lee YL: Glial fibrillary acidic protein: GFAP - thirty-one years (1969-2000). Neurochem Res 2000;25:14391451.

12 Pelinka LE, Kroepfl A, Schmidhammer R, Krenn M, Buchinger W, Redl H, Raabe A: Glial fibrillary acidic protein in serum after traumatic brain injury and multiple trauma. J Trauma 2004;57:1006-1012.

13 Blennow M, Hagberg H, Rosengren L: Glial fibrillary acidic protein in the cerebrospinal fluid: a possible indicator of prognosis in full-term asphyxiated newborn infants? Pediatr Res 1995;37:260-264.

$\checkmark 14$ Hsu AA, Fenton K, Weinstein S, Carpenter J, Dalton H, Bell MJ: Neurological injury markers in children with septic shock. Pediatr Crit Care Med 2008;9:245-251.
15 Jung CS, Foerch C, Schanzer A, Heck A, Plate KH, Seifert V, Steinmetz H, Raabe A, Sitzer M: Serum GFAP is a diagnostic marker for glioblastoma multiforme. Brain 2007;130: 3336-3341.

16 Scothorn DJ, Price C, Schwartz D, Terrill C, Buchanan GR, Shurney W, Sarniak I, Fallon R, Chu JY, Pegelow CH, Wang W, Casella JF, Resar LS, Berman B, Adamkiewicz T, Hsu LL, Ohene-Frempong K, Smith-Whitley K, Mahoney D, Scott JP, Woods GM, Watanabe M, Debaun MR: Risk of recurrent stroke in children with sickle cell disease receiving blood transfusion therapy for at least five years after initial stroke. J Pediatr 2002;140: 348-354.

17 Adams RJ, McKie VC, Hsu L, Files B, Vichinsky E, Pegelow C, Abboud M, Gallagher D, Kutlar A, Nichols FT, Bonds DR, Brambilla D: Prevention of a first stroke by transfusions in children with sickle cell anemia and abnormal results on transcranial Doppler ultrasonography. N Engl J Med 1998;339:5-11.

\section{Note Added in Proof}

An additional plasma GFAP level 21 months after stroke remained elevated at $0.535 \mathrm{ng} / \mathrm{ml}$. 